Disponível em

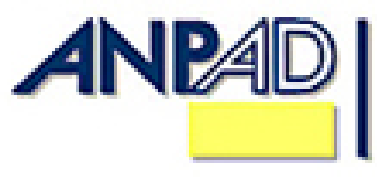

http://www.anpad.org.br/rac

RAC, Rio de Janeiro, v. 17, n. 4, art. 5, pp. 479-498, Jul./Ago. 2013

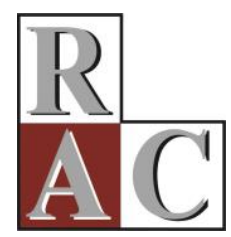

\title{
The Non-economic Dimension of Changes Prompted by Cross- border Acquisitions: A Relational View
}

Jeferson Vinhas Ferreira

E-mail: jefersonvf@hotmail.com

Centro Universitário do Sul de Minas - UNIS; Pontifícia Universidade Católica de São Paulo - PPGA/PUC-SP Rua Cel Ovidio Reis, 148, apto. 203, Centro, 37014-020, Varginha, MG, Brasil.

Angela França Versiani

E-mail: versiani@pucminas.br

Pontifícia Universidade Católica de Minas Gerais - PPGA/PUC Minas Av. Itaú, 525, Dom Cabral, 30535-012, Belo Horizonte, MG, Brasil.

Liliane Oliveira Guimarães

E-mail: lilianeog@pucminas.br Pontifícia Universidade Católica de Minas Gerais - PPGA/PUC Minas Av. Itaú, 525, Dom Cabral, 30535-012, Belo Horizonte, MG, Brasil. 


\title{
Resumo
}

A partir da visão relacional de F\&A proposta pela Abordagem de Redes Industriais, investigamos a dimensão não econômica das mudanças pós-aquisição nos relacionamentos da firma adquirida. Baseado em uma matriz $2 \mathrm{x}$ 2, essa dimensão é ilustrada pelos relacionamentos da adquirida com organizações com fins lucrativos nos quais recursos não econômicos são transacionados (denominados Sociais) ou com organizações sem fins lucrativos nos quais a adquirida transaciona recursos econômicos (denominados Parcerias) ou não econômicos (denominados Comunidades). Nós construímos um estudo de caso qualitativo a partir da aquisição da firma brasileira Grupo Paraíso pela multinacional suíça Holcim enfocando dez relacionamentos da firma adquirida. Os resultados indicam que esses relacionamentos mudaram em termos de profissionalização, grau de dependência e número de atores. O aumento da profissionalização é observado em todos os relacionamentos. Essa mudança (tipo e direção) foi considerada a mais importante mudança pós-aquisição. O grau de dependência e o número de atores aconteceram em segmentos específicos da rede da adquirida, representados pelos relacionamentos Comunidades e Sociais respectivamente.

Palavras-chave: mudança pós-aquisição; dimensão não econômica; relacionamentos; fusões e aquisições internacionais.

\begin{abstract}
Building on the relational view of M\&A suggested by the Industrial Network Approach, we looked at the noneconomic dimension of post-acquisition changes in the relationships of the acquired firm. Based on a $2 \times 2$ matrix, this is illustrated by the relationships between the acquired firm with for-profit organizations through which noneconomic resources are transacted (called Social) or with non-profit organizations with which it transacts either economic (called Partnership) or non-economic resources (called Community). We built a qualitative case study from the acquisition of the Brazilian firm Paraíso Group by the Swiss multinational Holcim, and focused on ten relationships of the acquired firm. We found that these relationships changed in terms of professionalism, degree of dependence and number of actors. An increase in professionalism is observed in all the relationships. This type and direction of change was considered the most important post-acquisition change. The degree of dependence and number of actors changes happened in specific segments of the acquired firm's network, represented by the Community and Social relationships, respectively.
\end{abstract}

Key words: post-acquisition change; non-economic dimension; relationships; cross-border mergers and acquisitions. 


\section{Initial Remarks}

Cross-border mergers and acquisitions (M\&A) are usually viewed as strategies for entering foreign countries more quickly (Elango \& Pattnaik, 2011) and achieving rapid growth in international markets (Chen, Chang, \& Lin, 2010), among other goals that firms usually pursue in the never-ending search for building and sustaining competitive advantages (Barnett, 2008).

The literature that follows the rise of M\&A is vast (Calipha, Tarba, \& Brock, 2010; Haleblian, Devers, McNamara, \& Carpenter, 2009), covering issues such as post-acquisition integration (Moore, 2011) and performance (Ambrosini, Bowman, \& Schoenberg, 2011; Das \& Kapil, 2012), knowledge retention (Child, Duarte, Tanure, \& Rodrigues, 2012) and changes in management practices (Duarte, 2001). It is interesting to notice that this literature highlights the roles played by the acquiring and acquired firms (Graebner \& Eisenhardt, 2004) based on the assumption that M\&A usually trigger changes that are mostly confined to this dyad (J. Anderson, Havila, \& Salmi, 2001).

This has been challenged by the Industrial Network Approach developed under the aegis of the Industrial Marketing and Purchasing Group (IMP Group) (Hakasson \& Snehota, 1995). Authors such as Havila and Salmi (2000) forcefully suggest that post-acquisition changes go beyond the dyad. This rather simple, yet powerful insight has stimulated research on M\&A at the network level whose results show that post-acquisition changes are either confined to the dyad or connected to dyad relationships (Bocconcelli, Snehota, \& Tunisini, 2006; J. Anderson et al., 2001). They also point out that M\&A potentially change network pictures (Oberg, Henneberg, \& Mouzas, 2007) and power relations in the relationships between the acquired firm and first-tier buyers and suppliers (Esper et al., 2010; Forsgren \& Olsson, 1992; Rezende \& Duarte, 2004; Oberg, Grundstrom, \& Jonsson, 2011).

Despite these achievements, we notice that this stream of research singles out relationships between the acquired firm and its connected buyers and suppliers (Ferreira, 2011), that is to say, forprofit organizations with which the acquired firm usually transacts economic resources. It goes without saying that its results are bounded by this type of relationship (McEvily, Jaffee, \& Tortoriello, 2012; Shipilov \& Li, 2012). This raises a number of questions: are non-profit organizations connected to the dyad affected by M\&A? Are for-profit organizations that transact non-economic resources also affected by M\&A? To what extent do M\&A trigger changes at the network level that go beyond the relationships between the acquired firm and buyers and suppliers?

These questions are the starting point for this piece of research. It aims to identify and analyze the non-economic dimension of post-acquisition changes in the relationships of the acquired firm, and can be justified both at the empirical and theoretical levels. Empirically, there are anecdotes about multinationals acquiring firms located in relatively small cities that commonly triggered changes that far surpassed not only the boundaries of the dyad, but also the relationships between the acquired firm and buyers and suppliers (Duarte, 2001). Theoretically, to the best of our knowledge, we have not come across a single piece of research that addresses what we call the non-economic dimension of post-acquisition changes in acquired firm relationships. Here, this dimension is illustrated by three cells of a $2 \times 2$ matrix on which our theoretical framework rests. The first cell is called Social, and includes the relationships between the acquired firm and non-profit organizations in which economic resources flow (Hadjikhani \& Thilenius, 2009). The second cell, Community, embraces relationships between the acquired firm and non-profit organizations in which non-economic resources flow (Ritvala \& Salmi, 2010). The last cell is dubbed Partnership. It embraces relationships between the acquired firm with for-profit organizations through which non-economic resources are transacted (Easton \& Araujo, 1992, 1994). We built a qualitative case study to address these questions and looked at the acquisition of the Brazilian firm Paraíso Group by the Swiss multinational Holcim. Based on secondary as well as primary data, we examined the non-economic dimension of postacquisition changes in ten acquired firm relationships.

This article is organized as follows. Initially, we review the literature on post-acquisition changes beyond the dyad and build the theoretical framework that underpins our investigation. 
Subsequently, we detail the methodology, placing a particular emphasis on data analysis. We then proceed to describe and analyze the non-economic dimension of post-acquisition changes in acquired firm relationships. We conclude by discussing the theoretical implications of this piece of research, its contributions, limitations and suggestions for future studies.

\section{Theoretical Background}

The enormous literature that follows the rise of M\&A worldwide concentrates on analyzing a number of issues regarding the acquiring and the acquired firms (Calipha et al., 2010), such as performance (Das \& Kapil, 2012), knowledge retention (Child et al., 2012) and changes in management practices (Duarte, 2001), such as human resource practices (Weber \& Tarba, 2010). J. Anderson, Havila and Salmi (2001) suggest that this literature is grounded in the assumption that changes triggered by acquisitions are mostly confined to the dyad formed by the acquiring and the acquired firms. As a consequence, those changes that go beyond this dyad usually fall off the researchers' radar screens (Havila \& Salmi, 2000, 2002; Oberg, 2012).

By contrast, the Industrial Network Approach offers a different view by focusing on changes in acquired firm relationships (Havila \& Salmi, 2000, 2002), usually represented by first-tier buyers and suppliers (J. Anderson et al., 2001). More broadly, this approach places emphasis on interconnected relationships developed by actors for transacting resources and performing activities (Hakasson \& Snehota, 1995) as well as the network contexts that arise from these relationships (J. Anderson, Hakansson, \& Johanson, 1994). In adopting a mid-level analysis it avoids understanding changes by either isolating firm attributes (micro level) or environmental forces (macro level) (Halinen, Havila, \& Salmi, 1999). Johanson and Vahlne (2013, p. 195) nicely encapsulate this view by recalling that "what happens, happens in relationships". By the same token, Corsaro and Snehota (2012, p. 272) state that "relationships are generators, recipients, and transmitters of change". As this approach has been developed "in the context of firm's exchange relationships" (Mouzas, 2006, p. 1275), it relies heavily on qualitative case study as a research method (Paliwoda, 2011). Inspired by this relational view, authors such as Oberg and Holstrom (2006) and H. Anderson, Holstrom and Oberg (2012) argue that the dyad formed by the acquiring and the acquired firms does not operate in a vacuum, but is embedded in a network of relationships whose configuration is likely to be affected by M\&A. J. Anderson et al. (2001) suggest that M\&A can sometimes be justified on the basis that the acquiring firm intends to broaden its relationship portfolio by incorporating the acquired firm's relationships.

Halinen, Salmi and Havila (1999) go further by introducing the concepts of confined and connected post-acquisition changes in order to shed some light on changes at the network level. Confined changes are those changes that remain within the boundaries of the dyad, whereas connected changes affect actors connected to the dyad, such as buyers and suppliers. An example of connected change can be viewed in Hertz's article (1998) where she uses the metaphor of dominos to show how rapidly changes triggered by M\&A spread to the network.

Following this pioneering work, other categorizations of post-acquisition changes at the network level have been proposed in the literature. For example, J. Anderson et al. (2001) put forward that they can be classified into intended and unexpected. Intended changes are those that are usually planned ex ante the acquisition whereas unexpected changes refer to emerging changes, that is to say, they happen ex post the acquisition out of the blue. Building on Easton (1992), they can also be classified into either evolutionary or revolutionary. Evolutionary changes imply the maintenance of actors and relationships, while revolutionary changes mean network reconfiguration in terms of number of actors and relationships (Degbey \& Pelto, 2013). Number of actors and relationships is therefore used to categorize whether a change following M\&A is either evolutionary or revolutionary.

Havila and Salmi (2000) say that evolutionary changes are more common in networks as actors tend to avoid terminating relationships built over the years. Accumulation of social capital and 
network imprint are seen as mechanisms for explaining network dynamics in terms of evolutionary changes (McEvily et al., 2012).

Interestingly enough, Halinen et al. (1999) propose that evolutionary and revolutionary changes coexist in the network after M\&A. This means that parts of the network undergo changes channeled through existing relationships (Easton, 1992), whereas other segments go through a radical transformation by including new actors as well as relationships, and/or excluding actors with the end of relationships (Degbey \& Pelto, 2013). In this sense, M\&A may simultaneously trigger evolutionary and revolutionary changes at the network level.

By adopting a different, yet complementary viewpoint, Forsgren and Olsson (1992), Esper et al. (2010) and Rezende and Duarte (2004) introduce a political view to explain post-acquisition changes at the network level. In doing so, they underscore the degree of dependence between actors and how it changes after M\&A. Forsgren and Olsson (1992) posit that M\&A are likely to disturb power relations in the network, which means that a particular actor can become more or less dependent on the acquired firm as a result of M\&A. Rezende and Duarte (2004) put forward a slightly different view. Instead of regarding the degree of dependence as the dependent variable, they suggest that it is the mediating variable. Accordingly, the acquired firm's potential and/or exercised power is affected by M\&A and this, in turn, influences the introduction of new management practices such as marketing and production into acquired firm relationships. Esper et al. (2010) propose an alternative view by hypothesizing that the degree of dependence is the moderating variable. Based on Emerson (1962) and Cook (1977), their model suggests that M\&A trigger economic and non-economic changes, this causal relationship being contingent on the degree of dependence between the dyad and buyers and suppliers.

All in all, it can be said that the Industrial Network Approach broadens our understanding of M\&A to the extent that it calls attention to the effects of M\&A at the network level (Bocconcelli et al., 2006; H. Anderson et al., 2012; Oberg, 2009). However, it places particular emphasis on a single type of relationship represented by the acquired firm and its buyers and suppliers (J. Anderson et al., 2001) and makes a simplifying assumption that these actors usually transact economic resources (Easton \& Araujo, 1992). As a result, non-economic actors with which the acquired firm establishes relationships are disregarded (Ferreira, 2011). By the same token, the relationships between the acquired firm and buyers and suppliers involving non-economic resources are neglected. To put it bluntly, the noneconomic dimension of post-acquisition changes in the relationships of the acquired firm remains backstage.

In order to help correct this, we devise a new theoretical framework based on the assumption that the acquired firm establishes various types of relationships (Hadjikhani \& Thilenius, 2009) for transacting economic and non-economic resources (Easton \& Araujo, 1992) that are likely to be affected by M\&A (Johanson \& Vahlne, 2009). In doing so, we are able to model the non-economic dimension of post-acquisition changes in acquired firm relationships.

Our theoretical framework, illustrated by a $2 \times 2$ matrix, rests on two variables: types of actors and types of resources. Actors are individuals and/or organizations with "perceptions, knowledge and capabilities" (Hakasson \& Senhota, 1995, p. 192) whereas resources refer to "any valued activity, service or commodity" (Cook, 1977, p. 64). Actors and resources involve economic and non-economic dimensions (Easton \& Araujo, 1992).

The economic dimension of actors is represented by for-profit organizations, that is to say, firms whose profits are usually distributed to their owners or stockholders. The non-economic dimension of actors is, in turn, illustrated by non-profit organizations. They are collective actors that exist for education, health, charitable reasons, amongst other purposes. Their profits are usually used for running operations rather than being distributed to their founders, officers and participants.

With regards to resources, their economic dimension refers to exchanges that involve monetary payment. According to Easton and Araujo (1992), exchanges in which economic resources are transacted are more visible, regular and predictable compared to exchanges that do not involve 
monetary payment for what is exchanged, this being equivalent to the non-economic dimension of resources. Examples of the non-economic dimension of resources include exchange of symbolic resources such as legitimacy and referrals (Faria \& Wensley, 2002) and exchange or share of equipment (Easton \& Araujo, 1992).

The combination of types of actors and types of resources produces four cells, each one corresponding to a specific part of the acquired firm's network, also dubbed net (Easton, 1992): Commercial, Social, Community and Partnership (see Table 1). The first cell, Commercial, accounts for relationships with for-profit organizations in which economic resources flow. The other three cells, Social, Community and Partnership, represent what we call the non-economic dimension. In these cells at least one variable assumes a non-monetary value: type of actor (non-profit organization) or type of resource (non-economic resource).

Table 1

\section{Theoretical Matrix}

\begin{tabular}{ccc}
\hline Actors/Resources & Economic & Non-economic \\
\hline For-profit Organization & Commercial & Partnership \\
Non-profit Organization & Social & Community \\
\hline
\end{tabular}

Note. Economic dimension: Commercial. Non-economic dimension: Social, Community and Partnership. Source: Authors.

The Commercial cell comprises the relationships through which economic resources flow between the acquired firm and for-profit organizations. Usually, these for-profit organizations are illustrated by the acquired firm's first-tier buyers and suppliers (J. Anderson et al., 2001; Oberg \& Holtstrom, 2006). As discussed earlier, research on M\&A at the network level usually concentrates on post-acquisition changes in this type of relationship (Havila \& Salmi, 2000, 2002; Oberg, 2009). Because this cell illustrates the economic dimension of post-acquisition changes in the relationships of the acquired firm, we leave it out of our analysis.

The Social cell includes the relationships between the acquired firm and non-profit organizations in which economic resources flow. This net comprises cases where the acquired firm funds social projects developed by connected non-profit organizations. It is expected that these relationships can be affected by M\&A to the extent that funding can be interrupted. Alternatively, the rules that govern it can be rethought. More radically, the relationships between the acquired firm and these organizations can be terminated after the acquisition.

The Community cell encompasses relationships between the acquired firm and non-profit organizations in which non-economic resources flow. This net usually corresponds to cases where the acquired firm is deeply involved in the community area where it is established (Ritvala \& Salmi, 2010). The impact of M\&A can be enormous, leading the non-profit organizations to rethink their roles and ties with the acquired firm because of lay-offs and new socio-political engagements of the acquired firm (Hadjikhani, Lee, \& Ghauri, 2008).

Finally, the Partnership Cell includes relationships between the acquired firm and for-profit organizations in which non-economic resources flow. This net is well illustrated by relationships between competitors for exchanging information or symbolic resources, such as legitimacy and referrals (Easton \& Araujo, 1992, 1994; Faria \& Wensley, 2002). M\&A are likely to change how these actors transact non-economic resources (Roseira, Brito, \& Henneberg, 2010). Alternatively, they can either reinforce or terminate these relationships (Kato \& Schoenberg, 2012).

In summary, our matrix accounts for three cells susceptible to change by M\&A, each one comprising particular types of relationships. These three cells altogether form the network of the acquired firm in which a non-economic dimension is involved. In terms of theory development, the 
matrix sheds some new light on the non-economic dimension of post-acquisition changes beyond the dyad.

\section{Methodology}

Following Halinen and Tornoos' (2005) recommendations for studying changes in networks, in particular the empirical investigations that subscribe to the IMP Group (Corsaro \& Snehota, 2012; Paliwoda, 2011), we chose a qualitative case study as the research method (Batt, 2012; Woodside, 2010). In this sense, we report here the case of the non-economic dimension of post-acquisition changes in acquired firm relationships (Byrne \& Ragin, 2009).

Three boundary conditions guided the empirical case selection (Yin, 2005). Firstly, we defined that over the years the acquired firm should have established relationships with for-profit and essentially non-profit organizations in which post-acquisition changes could have happened. Based on Duarte (2001), we were aware that this would be easier if the acquired firm were located in a relatively small city. Secondly, we privileged industrial firms (acquiring and acquired firms) as this piece of research is grounded in the literature on industrial networks (Hakasson \& Snehota, 1995). Last, but not least, a previous investigation indicated that the acquisition of Paraíso Group by the multinational Holcim was highly likely to be a fertile empirical case (Freitas, Rezende, \& Castro, 2008).

Having received consent from the Holcim Institute, we started collecting secondary and primary data concurrently. We collected secondary data from a number of sources, such as a local newspaper (Barroso em Dia), Holcim's newsletters and annual reports, and newsletters of non-profit organizations with which the acquired firm had established relationships (Instituto ABC and ADPIBAR). This data was later coded and compiled, resulting in nearly 200 pages of doubled-space text.

The primary data came from face-to-face interviews guided by a protocol. Initially, on May 10, 2011, we interviewed the coordinator of social programs at Holcim. We began the interview by showing our theoretical matrix in order to encourage him to point out relationships between the acquired firm and for-profit and non-profit organizations that fit the cells that interested us most, that is to say: Social, Community and Partnership. Having done this, he suggested that we interview two local authors as well. According to him, they were highly knowledgeable about the history of Barroso, as well as of the acquisition process. Finally, he explained the changes in the relationships between the acquired firm and those organizations that he considered relevant.

Following the first interview, we were able to interview all but three of the individuals in charge of all organizations that were previously suggested. Despite our best efforts, the City Hall's and the Santana Barroso Church's representatives remained silent to our request. As a result, we left them out of our inquiry. We were not able to interview the competitors' managers as well. In this sense, the information about the relationships between the acquired firm and these actors was retrieved and subsequently triangulated from the following sources: (a) in a previous investigation involving the same acquiring and acquired firms (Freitas et al., 2008), an extensive database was built upon articles from newspapers such as Estado de Minas, Estado de São Paulo, Folha de S.Paulo, Gazeta Mercantil and Valor as well as Holcim's newsletters and internal reports; (b) Holcim's latest newsletters and internal reports; and (c) an interview done with an individual from the acquiring firm, who, at the time of the interview, had more than 30 years of experience of dealing with them.

The fourteen interviews were carried out between May $11^{\text {th }}$ and July $1^{\text {st }}$ in Barroso, Minas Gerais state, Brazil, with founders, representatives or officers of the organizations They lasted one hour and ten minutes on average and some of them were tape-recorded. Later, they were transcribed, producing 50 pages of single-spaced text. In those interviews that were not tape recorded at the requests of the interviewees, we opted to take notes. 
The interviews were guided by a protocol composed of two sets of questions. The first aimed to get an overview of the relationship between the organization and the acquired firm before the acquisition. Questions such as Could you please describe how the relations between your organization and Paraíso Group developed over time? and What aspects (or factors) would you choose to depict this relation? are illustrative. The second intended to delve into the impacts of the acquisition on the relationship between the organization and Paraíso Group. To do so, we formulated a broad question asking the interviewee to describe how the acquisition influenced the relationship between the organization and the acquired firm (In our view, did the acquisition affect the relation between your organization and Paraíso Group? If so, how did it?). Based on what was said, we encouraged her or him to detail what changed after the acquisition. Finally, for each type of change s/he explained we asked her or him to go back as far as before the acquisition and describe what it was like by that time. In doing so, a preliminary comparison between a particular change before and after the acquisition was drawn during the interview. The inductive data analysis began by merging secondary and primary data texts, which, in turn, enabled us to triangulate data on two levels (Jick, 1979): secondary data vis-à-vis primary data as well as primary data itself. As a number of divergences were found, we contacted some interviewees either by e-mail or by phone so as to make some issues clearer.

Our next step in terms of data analysis involved building a spreadsheet in which we inserted all post-acquisition changes that emerged during triangulation. In total 65 post-acquisition changes were initially identified. Whilst doing this, we noticed that some changes referred to intra-organizational changes, whereas others were indirect changes (Degbey \& Pelto, 2013); i.e., they happened in the relationships between an organization connected to the acquired firm and an organization not connected to it. Yet, we found that some changes could not be associated with the acquisition itself.

This made our data analysis much harder as we were compelled to certify that a particular change not only had been triggered by the acquisition of Paraíso Group by Holcim, but also had happened in each of the three types of relationships suggested by our theoretical matrix: the acquired firm transacting either economic or non-economic resources with non-profit organizations, or the acquired firm transacting non-economic resources with for-profit organizations.

A back and forth analysis between the original and the merged documents was carried out for a while (Eisenhardt, 1989). As a result, six types of post-acquisition changes survived: professionalism in term of relationships, formalism, degree of dependence, professionalism in terms of social project management, number of organizations and professionalism in terms of organizational management.

With the aim of grouping some of these changes into a sort of second-order type of change, we decided to go deeper into the data analysis. We initially analyzed whether these six types of postacquisition changes were similar in terms of content. If positive, special attention was paid to the direction of change. Following George and Bennett (2005), we established that changes would be grouped only if they had changed in the same direction in all relationships in which they were manifested. A three-point scale was adopted for doing this: increase, no change and decrease.

This was far from easy as it meant going back to the original documents once again and to the initial spreadsheet that, at this stage, comprised six spreadsheets. Our aim was to make a correspondence between a particular change before and after the acquisition in terms of type and direction of change.

As a result, we found that professionalism in terms of relationships, formalism, professionalism in terms of social project management and professionalism in terms of organizational management could be grouped into professionalism. The degree of dependence and number of organizations, which was later relabeled number of actors, remained as distinct types of change.

Having certified that this categorization was robust enough, we associated each type of change (professionalism, degree of dependence, number of actors) and direction of change (increase, no 
change, decrease) with each relationship investigated and spread the results across the three cells of our matrix. This was a springboard for comparing changes in the relationships in and across cells.

The comparison in-cells meant identifying whether typical changes would emerge in each cell. We established that a typical change would be illustrated by the frequency of the relationships. From a theoretical standpoint, this corresponds to the non-economic dimension of post-acquisition changes that took place in parts of the acquired firm's network.

In turn, the comparison across cells involved pointing to the non-economic dimension of postacquisition changes by considering the three cells altogether, that it is to say, the acquired firm's network. It was required that at least one typical change emerged in each cell, which, in fact, fortunately happened. Subsequently, we compared it using, once again, the frequency criteria. These results are detailed in the next section.

\section{Results}

\section{Introducing the actors and the acquisition}

The acquiring firm is the Swiss multinational Holcim and the acquired firm is the Brazilian firm Paraíso Group. The former has been operating in Brazil since the 1950s. It entered the Brazilian market by acquiring a local firm. Since then, it has made a number of local acquisitions, including Paraíso Group. The latter was founded in 1945 by establishing a plant in the state of Rio de Janeiro. In the following three years, it set up three more plants in different states in Brazil. It is interesting to note that in 1966 Holcim made an agreement with Paraíso Group in order to buy a local cement maker. Due to a number of management divergences, four years later it sold its share to Paraíso Group.

The acquisition of Paraíso Group took place in 1996, comprised its four plants and triggered a number of changes in the Brazilian firm's relationships. Here, we focus on post-acquisition changes in the relationships between the Barroso unit, within the acquired firm, and ten for-profit and non-profit organizations, categorized in three cells: Social, Community and Partnership.

\section{Post-acquisition changes: social cell}

The Social cell comprises the relationships between the acquired firm and the Holcim Institute (S1), the Ortopolis Association of Barroso (AOB) (S2) and the Fathers' and Friends' Impaired People Association (APAE) (S3). The post-acquisition changes in these relationships can be seen in Figure 1. Broadly speaking, professionalism changed in all relationships classified into this cell. The direction of change is positive, which means that professionalism increased. In turn, the degree of dependence changed in S1 and S2 although in opposite directions, and remained unchanged in S3. Finally, the number of actors increased in S1 and S2 and, again, remained unchanged in S3. 


\begin{tabular}{|cccc|}
\hline Changes & \multicolumn{2}{c|}{ Relationships } \\
\hline Professionalism & S1 & S2 & No Change \\
Degree of dependence & & & No Change \\
Number of actors & $\mathbf{1}$ & $\mathbf{1}$ & No \\
\hline
\end{tabular}

Figure 1. Post-acquisition Changes: Social Cell.

Source: Authors.

The first change, professionalism, happened in all relationships of the Social cell. The direction of change is positive, that is to say, professionalism increased. Interestingly, this type of change was considered the most important change in this cell by the interviewees. In S1, professionalism is related to how the acquired firm deals with the social projects developed for the Barroso area. Via the Holcim Institute, it has adopted what is dubbed Social Engagement Scorecard (SES). This is viewed as a tool for analyzing social projects by measuring the degree of the social engagement of the project as well as establishing steps through which the social projects are required to go through before approval. As a consequence, after the acquisition, the decision-making process has become more impersonal. According to one interviewee, "before the acquisition the managers decided where and how much the company would spend the money. It was a personal decision. Nowadays, we have clear guidance (referring to SES) and we work accordingly". It is noteworthy that the Holcim Institute has been considering another tool for analyzing social projects. Termed as Community Engagement Plant (CEP), its aim is to enable it to identify relevant stakeholders and the social projects that interest it most. In S1, professionalism is also related to the absence of political alignment between the acquired firm and the local actors as a critical factor for selecting social projects. Specifically, it was said that before the acquisition, social projects were tailored to individuals and organizations that were considered as "politically aligned with the company". This interviewee added, saying that "this ended radically by adopting an apolitical way to analyze social projects".

In S2, professionalism has to do with how AOB deals with the social projects sponsored by the acquired firm. It was pointed out that before the acquisition, there was neither an organization nor an individual who developed and managed self-sustaining projects that reflected the interests and needs of the local area. With the help of the institute, it was said that AOB has been able to change this by prioritizing self-sustaining projects and mobilizing local actors to implement them. Similar to S1 and $\mathrm{S} 2$, in S3, professionalism is related to the adoption of tools such as SES and CEP for analyzing social projects developed by APAE.

The degree of dependence, the second change in the Social cell, decreased in S1, increased in S2 and remained unchanged in S3. In S1, the degree of dependence refers to the financial dependence of the institute on the acquired firm. According to the interviews, before the acquisition, the selected social projects were $100 \%$ financed by the acquired firm. This has been changed gradually by establishing that the institute must obtain $50 \%$ of the financial resources required by the social projects from external sources. The idea is to decrease the financial dependence on the acquired firm. A different situation is experienced by AOB. It was said that the acquired firm would support AOB financially in its initial steps only. However, as the number of social projects under the umbrella of $\mathrm{AOB}$ skyrocketed, the degree of dependence on the acquired firm increased considerably. This was because AOB has been unable to secure financial resources for the social projects from external sources. In S3, there was no evidence of post-acquisition changes in terms of the degree of dependence between APAE and the acquired firm.

The number of actors is the last post-acquisition change in the Social Cell. It increased in S1 and S2 and remained unchanged in S3. In S1 and S2, this change is illustrated by the creation of the Holcim Institute and $\mathrm{AOB}$ respectively. The former not only helped found the latter, but also affected 
the number of local non-profit organizations seeking to have their social projects approved by the institute. By mobilizing local actors, the latter assisted in creating the Recyclable Material Collector Association of Barroso (ASCAB) and the Milk Producer Association of Barroso and area (APLeiteBr). In S3, it was said that the number of actors remained unchanged.

\section{Post-acquisition changes: community cell}

The Community cell comprises the relationships between the acquired firm and the following organizations: the City Council of Barroso (C1), Commercial, Industrial and Agricultural Association of Barroso (ACIB) (C2), Construction Building and Furniture Union (C3), Association of São José District (ABSJ) (C4), Diabetic People Association of Barroso (APDIB) (C5) and Improving Literacy for Citizenship Welfare Institute (ABC) (C6).

Figure 2 summarizes the post-acquisition changes in the Community cell. In general, professionalism increased in all relationships of this cell. The degree of dependence decreased in three relationships $(\mathrm{C} 4, \mathrm{C} 5$ and $\mathrm{C} 6)$, increased in one $(\mathrm{C} 2)$ and remained unchanged in two relationships $(\mathrm{C} 1$ and $\mathrm{C} 3)$. The number of actors remained unchanged in three relationships (C1, C2 and $\mathrm{C} 3)$ and increased in three relationships $(\mathrm{C} 4, \mathrm{C} 5$ and $\mathrm{C} 6)$.

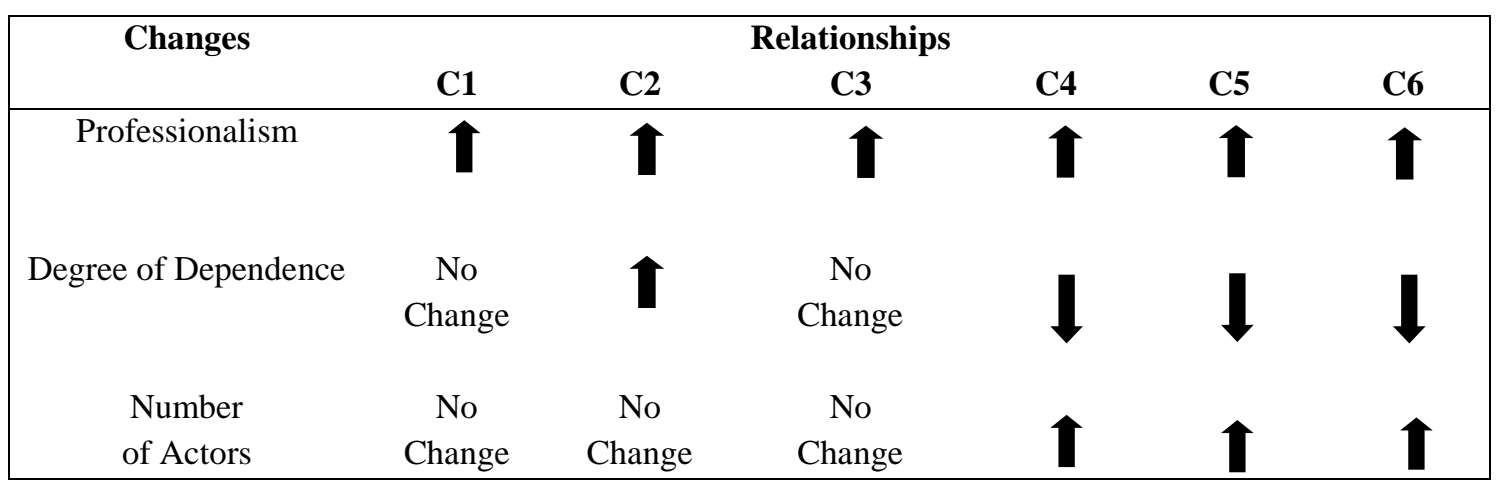

Figure 2. Post-acquisition Changes: Community Cell.

Source: Authors.

Similar to the Social cell, professionalism increased in all Community cell relationships. In C1, professionalism has to do with the relationships between the acquired firm and the City Council of Barroso. One interviewee said that before the acquisition the councilors' pleas were analyzed according to the degree of political alignment between the proponents and the acquired firm's managers. According to him, "this has changed enormously" as the acquired firm has adopted, via the Holcim Institute, tools for analyzing social projects. In addition, it has established a particular area called External Relations for dealing with its major stakeholders, including the City Council. In C2, the relationship between the firm and ACIB has become more professional as the acquired firm has engaged in a number of activities carried out by the association such as training and consulting. In addition, the acquired firm has accepted an invitation to have a seat on the board of the association. In doing so, it has helped the association with a number of management projects directed at its members. In C3, the increase of professionalism is, according to one interviewee, related to the establishment of a formal dialogue between the acquired firm and the union. Although the president of the union was criticized for allowing this, it was said that the relationship between the acquired firm and the union has evolved positively to the extent that there have been more negotiations and agreements between them. In addition, it was pointed out that the acquired firm has adopted a number of formal HR practices such as recruiting, training and fringe benefits that, in turn, have made the negotiations between the acquired firm and the union easier. In $\mathrm{C} 4$ and $\mathrm{C} 5$, professionalism refers to the decisionmaking process related to social projects. As aforementioned, tools for analyzing social projects have been adopted by the acquired firm via the Holcim Institute. In C6, it was mentioned that the acquired firm not only has helped the association implement the approved social projects, but it also has supplied it with cost-free managerial expertise such as cost control tools. 
The degree of dependence remained unchanged in $\mathrm{C} 1$ and $\mathrm{C} 3$, increased in $\mathrm{C} 2$ and decreased in $\mathrm{C} 4, \mathrm{C} 5$ and $\mathrm{C} 6$. In relation to $\mathrm{C} 2$, it was pointed out that the degree of dependence on the acquired firm increased to the extent that ACIB has managed to implement all projects with the assistance of the acquired firm. In C4, C5 and C6, it was said that they have become less dependent on the acquired firm as they have managed to secure some financial resources for their social projects from external sources. As highlighted by one interviewee, "before the acquisition, they milked the company. The company was their cow. After the acquisition, they had to reorganize themselves so as to survive. As a result, the dependence decreased".

In terms of number of actors, it remained unchanged in $\mathrm{C} 1, \mathrm{C} 2$ and $\mathrm{C} 3$ and increased in $\mathrm{C} 4, \mathrm{C} 5$ and C6. With regards the former, our data point out that the number of actors remained unchanged in the relationships between the acquired firm and the City Council, the union and ABSJ. In relation to the latter, it was mentioned that the acquisition stimulated the emergence of a number of associations such as those analyzed here: ABSJ, APDIBAR and ACIB. It is interesting to notice that these nonprofit organizations have been run either by the acquired firm's former workers or by their sons.

\section{Post-acquisition changes: partnership cell}

In terms of post-acquisition changes in the Partnership cell, our data point out that professionalism is the only variable that changed in the relationships between the firm and competitors. In this sense, the degree of dependence and the number of actors remained unchanged (see Figure 3).

\begin{tabular}{|cc|}
\hline Changes & $\begin{array}{c}\text { Relationships } \\
\text { P1 }\end{array}$ \\
\hline Professionalism & 1 \\
Degree of Dependence & No Change \\
Number of Actors & No Change \\
\hline
\end{tabular}

Figure 3. Post-acquisition Changes: Partnership Cell.

Source: Authors.

With regards to professionalism, it was mentioned that before the acquisition, there were informal meetings between the acquired firm and competitors so as to exchange information as well as assist each other with technical issues. It was also recalled that one eventually borrowed equipment and machines from the other and vice-versa. After the acquisition, following Holcim's worldwide guidelines, the acquired firm has established that these meetings could only happen via business associations, in particular the Portland Cement Brazilian Association (ABCP), in order "to organize how these transactions take place and to formalize them".

According to our data, the degree of dependence between the acquired firm and its competitor did not change as a consequence of the acquisition of the Barroso unit. This is similar to the number of actors.

\section{Post-acquisition changes: across cell comparison}

Having described the post-acquisition changes in the Social, Community and Partnership cells, we now turn to the comparison across cells. As shown in Figure 4, the direction of change is crystalclear in professionalism only. It increased in all cells. 


\begin{tabular}{|cccc|}
\hline Change & Social & $\begin{array}{c}\text { Cell } \\
\text { Community }\end{array}$ & Partnership \\
\hline Professionalism & No Conclusion & No Conclusion & No Change \\
Degree of Dependence & 1 & No Change \\
\hline
\end{tabular}

Figure 4. Post-acquisition Changes: Across Cell Comparison.

Source: Authors.

Professionalism increased in the Social, Community and Partnership cells. In general, this type of post-acquisition change means that the rules that govern the relationships between the acquired firm and the profit and non-profit organizations have become more explicit and standardized. As shown earlier, this is nicely illustrated by the way the acquired firm has been funding the social projects developed by connected non-profit organizations in the Barroso area. A common theme in the interviews is that before the acquisition there were no explicit criteria for picking them up. According to some interviewees, it seemed that personal relationships between the acquired firm's managers and the proponents mattered a lot. This has changed to the extent that tools for analyzing social projects have been adopted by the acquired firm via the Holcim Institute. To a certain degree, this, in turn, has immunized the acquired firm from personal influences and demands. Regardless of the cell, professionalism was considered the most profound and critical change that has followed the acquisition of Paraíso Group by Holcim.

The direction of change of the degree of dependence and the number of actors is much less clear. With regards the former, it decreased in the Community cell and remained unchanged in the Partnership cell. As reported earlier, no conclusion can be drawn from the Social cell in terms of degree of dependence because the direction of change was different in its three relationships. In relation to the latter, the number of actors increased in the Social cell and remained unchanged in the Partnership cell. No conclusion can be drawn from the Community cell. Therefore, the direction of change is considered balanced in this cell as it increased in three relationships and decreased in three relationships.

\section{Discussion}

From a broader viewpoint, we found that M\&A triggered changes in the relationships of the acquired firm formed with actors other than buyers and suppliers in which either non-economic or economic resources are transacted. On the one hand, we lend some support to the relational view of M\&A (Halinen et al., 1999; Havila \& Salmi, 2000, 2002), as we point out that M\&A trigger changes that go beyond the dyad formed by the acquiring and the acquired firms (H. Anderson et al., 2012). In this sense, we present additional evidence that post-acquisition changes are not only confined, but also connected to the dyad (Halinen et al., 1999), thus contributing to an emerging literature grounded in the Industrial Network Approach (H. Anderson et al., 2012; Bocconcelli et al., 2006; Oberg, 2009).

On the other hand, we introduce a different, yet complementary view to the extent that we propose that M\&A are more contagious than suggested in the extant literature (Oberg \& Holstrom, 2006). This means that M\&A trigger changes in the relationships of the acquired firm with for-profit organizations vis-à-vis economic resources, non-profit organizations vis-à-vis non-economic resources and non-profit organizations vis-à-vis economic resources. In doing so, we zoom in on the non- 
economic dimension of post-acquisition changes in acquired firm relationships, a topic that has received scant attention in the literature on industrial networks (Hadjikhani \& Thilenius, 2009).

Although not exhaustive, three types of changes illustrate the non-economic dimension of postacquisition changes: professionalism, degree of dependence and number of actors (see Figure 5).

\begin{tabular}{|c|c|c|}
\hline Actors/Resources & Economic & Non-economic \\
\hline \multirow[t]{2}{*}{ For-profit Organization } & Commercial & Partnership \\
\hline & & Professionalism \\
\hline \multirow[t]{2}{*}{ Non-profit Organization } & $\begin{array}{c}\text { Social } \\
\text { Professionalism }\end{array}$ & $\begin{array}{c}\text { Community } \\
\text { Professionalism }\end{array}$ \\
\hline & Number of Actors & Degree of Dependence \\
\hline
\end{tabular}

Figure 5. The Non-economic Dimension of Post-acquisition Changes in the Relationships of the Acquired Firm.

Economic dimension: Commercial. Non-economic dimension: Social, Community and Partnership. Source: Authors.

The increase of professionalism is observed in the relationships of the acquired firm in which a non-economic variable - actor or resource - is involved. On top of it, this type and direction of change was considered the most important post-acquisition change. Interestingly enough, this finding has not been reported in the literature on M\&A at the network level (Havila \& Salmi, 2000, 2002), even in those empirical studies that place particular emphasis on types of managerial changes that follow M\&A (Degbey \& Pelto, 2013; Esper et al., 2010; Freitas et al., 2008). As this piece of research is, to our knowledge, the first to delve into the non-economic dimension of post-acquisition changes in acquired firm relationships, we present preliminary evidence that professionalism is a typical noneconomic post-acquisition change beyond the dyad. It goes without saying that this is subject to empirical testing.

Differently from professionalism, the other two types of changes identified here - degree of dependence and number of actors - have been reported in the studies that analyze the economic dimension of post-acquisition changes which, as argued earlier, is usually illustrated by the relationships of the acquired firm with buyers and suppliers in which economic resources are transacted (Bocconcelli et al., 2006; Oberg et al. 2011; Oberg \& Holstrom, 2006).

In terms of degree of dependence, we found that this type of change happened in the Community cell only, which represents the segment of the acquired firm's network comprised of relationships with non-profit organizations in which non-economic resources flow. In addition, the direction of change is negative, indicating a decrease of dependence by non-profit organizations on the acquired firm. Theoretically, this result is line with Forsgren and Olsson (1992) who posit that M\&A trigger changes in terms of degree of dependence between actors, either positively or negatively. As the degree of dependence assumes the role of the dependent variable, here it is suggested that it is a type of change that follows M\&A. In this sense, it takes on the role of neither the mediating (Rezende \& Duarte, 2004) nor the moderating (Esper et al., 2010; Oberg et al., 2011) variable in M\&A at the network level. Based on this, we recommend that future empirical studies should contrast these views in order to shed more light on the role of the degree of dependence in the non-economic dimension of post-acquisition changes in the relationships of the acquired firm. Bounded by our results, we must bear in mind that this suggestion does not necessarily imply taking into account the acquired firm's network, but rather segments of it as the locus where changes in terms of degree of dependence take place (Easton, 1992).

In relation to the last type of change unveiled in this piece of research, number of actors, we found that it changed in the Social cell, which represents the relationships of the acquired firm with 
for-profit organizations in which non-economic resources flow. This means that this part of the network underwent revolutionary changes. We also found that it remained unchanged in the Partnerships cell, thus characterizing evolutionary changes after M\&A. From a theoretical standpoint, these results are fully consistent with the literature on M\&A at the network level (Freitas et al., 2008; Halinen et al., 1999), as it suggests that M\&A may simultaneously induce evolutionary and revolutionary changes in acquired firm relationships. As discussed earlier, this is equivalent to say that evolutionary changes coexist with revolutionary changes after M\&A (Degbey \& Pelto, 2013). In some parts of the network existing relationships are maintained whereas in other segments new relationships are formed and/or current relationships are broken off, both taking place concurrently (Halinen et al., 1999).

With these results in mind, we put forward that there seems to be a partial overlap between the economic and non-economic dimensions of post-acquisition changes beyond the dyad. By focusing on relationships that are the locus of the non-economic dimension of post-acquisition changes we zoom in on changes that have not been reported in the extant literature. To some degree, this lends empirical support to our initial contention that M\&A trigger changes that are contingent on types of relationships developed by the acquired firm. In doing so, we add a level of complexity to the relational view of M\&A by arguing that the non-economic dimension infuses heterogeneity into post-acquisition changes that go beyond the dyad (Corsaro, Cantù, \& Tunisini, 2012). We suggest that future research on M\&A at the network level should take this heterogeneity into account and make explicit which types of relationships are affected by M\&A (McEvily et al., 2012). In doing this, we will be paving the way for a finer-grained understanding of post-acquisition changes beyond the dyad.

\section{Concluding Remarks}

Previous studies carried out under the umbrella of the Industrial Network Approach such as those of Havila and Salmi $(2000,2002)$ emphasize the economic dimension of post-acquisition changes as they focus on the relationships between the acquired firm with buyers and suppliers in which economic resources flow. By contrast, our piece of research looks at the non-economic dimension of post-acquisition changes, illustrated by the relationships between the acquired firm with for-profit organizations through which non-economic resources are transacted and/or with non-profit organizations with which it transacts either economic or non-economic resources. Based on a theoretical framework illustrated by a $2 \times 2$ matrix, we built an exploratory qualitative case study from the acquisition of Paraíso Group by the multinational Holcim, and found that professionalism, degree of dependence and number of actors illustrated the non-economic dimension of post-acquisition changes beyond the dyad.

We believe that the major contributions of this research reside in two issues: (a) we looked at a dimension of post-acquisition changes in the relationships of the acquired firm neglected in the literature - the so-called non-economic dimension (Easton \& Araujo, 1992); (b) we built a fresh theoretical framework that can be used as a springboard for future studies.

Notwithstanding, these contributions should be viewed with caution. Firstly, our findings are based on a single case study that prevents us from making statistical generalization (Yin, 2005). Secondly, we selected a particular plant of Paraíso Group for closer scrutiny, thus leaving the other three plants out of the investigation. This prevents us from extending our findings to Paraíso Group as a whole. Yet, our results are bounded by a number of contextual factors such as industry, time, and geography (Poulis, Poulis, \& Plakoyiannaki, 2013). Nonetheless, this represents interesting, yet challenging opportunities for future research. In our view, this endeavor entails identifying and analyzing if and how a contextual factor (or groups of contextual factors) interferes in the nondimension of post-acquisition changes in the relationships of the acquired firm. In order to pursue this line of inquiry, a bridge between the Industrial Network Approach and another theoretical approach is likely to be required, the selection of this theoretical approach being contingent on the contextual 
factors picked up by the researcher. For example, Institutional Theory may be called forth provided the interest is in the institutional context in which relationships and networks are embedded (Scott, 2001). Thirdly, we interviewed representatives of organizations suggested by the first interviewee: the social program coordinator at Holcim. This might have introduced bias stemming from the fact that organizations were not selected randomly. Fourthly, despite our best efforts we were unable to interview some organizations, such as City Hall and Santana Barroso Church. We were also unable to interview the acquired firm's competitors. In order to take into account changes in the relationships between the acquired firm and competitors we ended up collecting and triangulating data from three types of rather independent indirect sources. In doing so, we did not rule out bias stemming from collecting data from these sources (Bluhm, Harman, Lee, \& Mitchell, 2011), but reduced it. Fifthly, we have not explicitly adopted a political view of M\&A even though our results highlight the degree of dependence as a particular type of change that followed the acquisition of Paraíso Group by the multinational Holcim (Faria, 2004; Welch \& Wilkinson, 2004). Last, but not least, we investigated an acquisition that took place in 1996. Although we collected secondary and primary data extensively and employed triangulation at two levels (Jick, 1979), past reconstruction is not a trivial endeavor (Keightley, 2010). Bias stemming from loss of memory at individual and collective levels should not be discarded.

\section{Acknowledgments}

Financial support to Sérgio Fernando Loureiro Rezende was provided by The National Council for Scientific and Technological Development (CNPq) and Fapemig Minas Gerais State Research Foundation (FAPEMIG). We thank the anonymous reviewers for their constructive comments. We are also grateful to Editor Herbert Kimura for his support and patience. All remaining errors are our own. This article is dedicated to Maria Amália de Freitas.

\section{References}

Ambrosini, V., Browman, C., \& Schoenberg, R. (2011). Should acquiring firms pursue more than one value creation strategy? An empirical test of acquisition performance. British Journal of Management, 22(1), 173-185. doi: 10.1111/j.1467-8551.2010.00693.x

Anderson, J., Hakasson, H., \& Johanson, J. (1994). Dyadic business relationships within a business network context. Journal of Marketing, 58(4), 1-15.

Anderson, J., Havila, V., \& Salmi, A. (2001). Can you buy a business relationship? On the importance of customer and supplier relationships in acquisitions. Industrial Marketing Management, 30(7), 575-586. doi: 10.1016/S0019-8501(99)00123-6

Anderson, H., Holstrom, J., \& Oberg, C. (2012). Do competition authorities consider business relationships. Journal of Business to Business Marketing, 19(1), 67-92. doi: 10.1080/1051712X.2011.593024

Barnett, W. (2008). The Red Queen among organizations: how competitiveness evolves. Princeton, NJ: Princeton University Press.

Batt, P. (2012). Measures and measurement: process and practice. Industrial Marketing Management, 41(3), 379-384. doi: 10.1016/j.indmarman.2012.02.002

Bluhm, D., Harman, W., Lee, T., \& Mitchell, T. (2011). Qualitative research in management: a decade of progress. Journal of Management Studies, 48(8), 1866-1891. doi: 10.1111/j.14676486.2010.000972.x 
Bocconcelli, R., Snehota, I., \& Tunisini, A. (2006). Network relationships and corporate acquisitions outcomes. The IMP Journal, 1(2), 1-55.

Byrne, D., \& Ragin, C. (2009). The Sage handbook of case-based methods. London: Sage.

Calipha, R., Tarba, S., \& Brock, D. (2010). Mergers and acquisitions: a review of phases, motives, and success factors. In C. Cooper \& S. Finkelstein (Eds.), Advances in mergers and acquisitions (Vol. 9, pp. 1-24). London: Emerald Group Publishing Limited.

Chen, C-H., Chang, Y-Y., \& Lin, M-Ji. (2010). The performance impact of post-M\&A interdepartamental integration: an empirical analysis. Industrial Marketing Management, 39(7), 1150-1161. doi: 10.1016/j.indmarman.2009.12.0002

Child, J., Duarte, R., Tanure, B., \& Rodrigues, S. (2012). Access to tacit knowledge by executive retention in cross-border acquisitions. Brazilian Administrative Review, 9(3), 329-350. Retrieved from http://www.scielo.br/pdf/bar/v9n3/a06v9n3.pdf. doi: 10.1590/S180776922012000300006

Cook, K. (1977). Exchange and power in networks of interorganizational relations. The Sociological Quarterly, 18(1), 62-82.

Corsaro, D., Cantù, C., \& Tunisini, A. (2012). Actors' heterogeneity in innovation networks. Industrial Marketing Management, 41(5), 780-789. doi: 10.0116/j.indmarman.2012.06.005

Corsaro, D., \& Snehota, I. (2012). Perceptions of change in business relationships and networks. Industrial Marketing Management, 41(2), 270-286. doi: 10.0116/j.indmarman.2012.01.002

Das, A., \& Kapil, S (2012). Explaining M\&A performance. Journal of Strategy and Management, 5(3), 284-330. doi: 10.1108/17554251211247580

Degbey, W., \& Pelto, E. (2013). Cross-border M\&A as a trigger for network change in the Russian bakery industry. Journal of Business \& Industrial Marketing, 28(3), 189-189. doi: $10.1108 / 08858621311302831$

Duarte, R. (2001). Cross-border acquisitions and changes in domestic management practices - the case of Brazil (Doctoral dissertation). The Judge Institute of Management, University of Cambridge, Cambridge, England.

Easton, G. (1992). Industrial networks: a review. In B. Axelsson \& G. Easton (Eds.), Industrial networks: a new view of reality (pp. 1-27). London: Routledge.

Easton, G., \& Araujo, L. (1992). Non-economic exchange in industrial networks. In B. Axelsson \& G. Easton (Eds.), Industrial networks: a new view of reality (pp. 62-84). London: Routledge.

Easton, G., \& Araujo, L. (1994). Market exchange, social structures and time. European Journal of Marketing, 28(3), 72-84. doi: 10.1108/03090569410057317

Eisenhardt, K. (1989). Building theories from case study research. Academy of Management Review, 14(4), 532-550.

Elango, B., \& Pattnaik, C. (2011). Learning before making the big leap: acquisition strategies of emerging market firms. Management International Review, 51(4), 461-481. doi: 10.007/s11575011-0085-0

Emerson, R. M. (1962). Power-dependence relations. American Sociological Review, 27(1), 31-41. doi: $10.2307 / 2089716$ 
Esper, L. T. G., Rezende, S., Versiani, A., Lopes, H., Guimarães, L., \& Duarte, R. (2010). Relações de poder e mudanças pós-aquisição internacional na rede de relacionamentos da adquirida. Revista de Administração Contemporânea, 14(4), 684-702. Retrieved from http://www.scielo.br/pdf/rac/v14n4/08.pdf. doi: 10.1590/S1415-65552010000400008

Faria, A. (2004). Uma proposta de framework em gerência estratégica de redes verticais ( $1^{\text {a }}$ Edição Especial). Revista de Administração Contemporânea, 11, 33-54. doi: 10.1590/S141565552007000500003

Faria, A., \& Wensley, R. (2002). In search of 'interfirm management' in supply chains: recognizing contradictions of language and power by listening. Journal of Business Research, 55(7), 603610. doi: 10.1016/S0148-2963(00)00190-9

Ferreira, J. (2011). Mudanças pós-aquisição na rede de relacionamentos da firma adquirida; proposta de um modelo teórico. Interação, 13(13), 86-98.

Forsgren, M., \& Olsson, U. (1992). Power balancing in an international business network. In M. Forsgren \& J. Johanson (Eds.), Managing networks in international business (pp. 178-192). Philadelphia, Penn: Gordon and Breach.

Freitas, M. A. M. de, Rezende, S. F. L., \& Castro, J. M. de (2008). Mudanças pós-aquisição internacional na rede de fornecedores da adquirida. Revista de Administração Contemporânea, 12(3), 811-834. doi: 10.1590/S1415-65552008000300010

George, A., \& Bennet, A. (2005). Case studies and theory development in the social sciences. Cambridge, Mass: MIT Press.

Graebner, M. E., \& Eisenhardt, K. M. (2004). The seller's side of the story: acquisitions as courtship and governance as syndicate in entrepreneurial firms. Administrative Science Quarterly, 49(3), 366-403. doi: 10.2307/4131440

Hadjikhani, A., Lee, J.-W., \& Ghauri, P. N. (2008). Network view of MNCs' socio-political behavior. Journal of Business Research, 61(9), 912-924. doi: 10.1016/j.jbusres.2007.10.001

Hadjikhani, A., \& Thilenius, P. (2009). Industrial relationships and the effects of different types of connections. Industrial Marketing Management, 38(6), 679-686. doi: 10.1016/j.indmarman.2009.05.011

Hakansson, H., \& Snehota, I. (1995). Developing relationships in business networks. London: Routledge.

Haleblian, J., Devers, C., McNamara, G., \& Carpenter, M. (2009). Taking stock of what we know about mergers and acquisitions: a review and research agenda. Journal of Management, 35(3), 469-520. doi: 10.1177/0149206308330554

Halinen, A., Salmi, A., \& Havila, V. (1999). From dyadic change to changing business networks: an analytical framework. Journal of Management Studies, 36(6), 779-794. doi: 10.1111/14676486.00158

Halinen, A., \& Tornroos, J.-A. (2005). Using case methods in the study of contemporary business networks. Journal of Business Research, 58(9), 1285-1297. doi: 10.1016/j.jbusres.2004.02.001

Havila, V., \& Salmi, A. (2000). Spread of change in business networks: an empirical study of mergers and acquisitions in the graphic industry. Journal of Strategic Marketing, 8(2), 105-119. doi: $10.1080 / 096525400346204$ 
Havila, V., \& Salmi, A. (2002). Network perspectives on international mergers and acquisitions: what more do we see? In V. Havila, M. Forsgren, \& H. Hakansson (Eds.), Critical perspectives on internationalization (pp.457-472). Oxford: Pergamon.

Hertz, S. (1998). Domino effects in international networks. Journal of Business-to-Business Marketing, 5(3), 3-31. doi: 10.1300/J033v05n03_02

Jick, T. (1979). Mixing qualitative and quantitative methods: triangulation in action. Administrative Science Quarterly, 24(4), 602-610.

Johanson, J., \& Vahlne, J-E. (2009). The Uppsala internationalization process model revisited: from liability of foreignness to liability of outsidership. Journal of International Business Studies, 40(9), 1141-1431. doi: 10.1057/jibs.2009.24

Johanson, J., \& Vahlne, J-E. (2013). The Uppsala model on evolution of the multinational business enterprise - from internalization to coordination of network. International Marketing Review, 30(3), 189-210. doi: 10.1108/02651331311321963

Kato, J., \& Schoenberg, R. (2012). Customer and competitor responses to mergers and acquisitions: an empirical investigation in the logistics industry. In C. Cooper \& S. Finkelstein (Eds.), Advances in mergers and acquisitions (Vol. 12, pp. 155-180). London: Emerald Group Publishing Limited.

Keightley, E. (2010). Remembering research: memory and methodology in the social sciences. International Journal of Social Research Methodology, 13(1), 55-70. doi: $10.180 / 13645570802605440$

McEvily, B., Jaffee, J., \& Tortoriello, M. (2012). Not all bridging ties are equal: network imprint and firm growth in the Nashville Legal Industry, 1933-1978. Organization Science, 23(2), 547-563. doi: 10.1287/orsc.1100.0633

Moore, F. (2011). Holistic ethnography: studying the impact of multiple national identities on postacquisition organizations. Journal of International Business Studies, 42(5), 654-671. doi: 10.1057/jibs.2011.11

Mouzas, S. (2006). Marketing action in networks. European Journal of Marketing, 40(11/12), 12711291. doi: $10.1108 / 03090560610702812$

Oberg, C. (2009). Who owns a customer relationship following a merger or acquisition? Corporate Ownership and Control, 6(2), 212-221.

Oberg, C. (2012). Mergers and acquisitions as embedded network activities. European Journal of International Management, 6(4), 421-441.

Oberg, C., Grundstrom, C., \& Jonsson, P. (2011). Acquisitions and network identity change. European Journal of Marketing, 45(9/10), 1470-1500. doi: 10.1108/03090561111151853

Oberg, C., Henneberg S. C., \& Mouzas, S. (2007). Changing network pictures: evidence from mergers and acquisitions. Industrial Marketing Management, 36(7), 926-940. doi: 10.1016/j.indmarman.2007.05.010

Oberg, C., \& Holstrom, J. (2006). Are mergers and acquisitions contagious? Journal of Business Research, 59(12), 1267-1275. doi: 10.1016/j.jbusres.2006.09.015

Paliwoda, S. J. (2011). Critically evaluating the IMP research contribution. Industrial Marketing Management, 40(6), 1055-1056. doi: 10.1016/j.indmarman.2011.07.002 
Poulis, K., Poulis, E., \& Plakoyiannaki, E. (2013). The role of context in case study selection: an international business perspective. International Business Review, 22(1), 304-314. doi: 10.1016/j.ibusrev.2012.04.003

Rezende, S., \& Duarte, R. (2004). Post-acquisition changes beyond the dyad: power at the net level in cross-border acquisitions. Brazilian Administration Review, 1(1), 67-80. Retrieved from http://www.anpad.org.br/periodicos/arq_pdf/a_619.pdf. $\quad$ doi: $\quad$ 10.1590/S180776922004000100006

Ritvala, T., \& Salmi, A. (2010). Value-based network mobilization: a case study of modern environmental networkers. Industrial Marketing Management, 39(6), 898-907. doi: 10.1016/j.indmarman.2010.06.009

Roseira, C., Brito, C., \& Henneberg, S. (2010). Managing interdependencies in supplier networks. Industrial Marketing Management, 39(6), 925-935. doi: 10.1016/j.indmarman.2010.06.012

Scott, R. (2001). Institutions and organizations. London: Sage Publications.

Shipilov, A., \& Li, S. (2012). The missing link: the effect of customers on the formation of relationships among producers in the multiplex triads. Organization Science, 23(2), 472-491. doi: $10.1287 /$ orsc. 1100.0568

Weber, Y., \& Tarba, S. Y. (2010). Human resource practices and performance of mergers and acquisitions in Israel. Human Resource Management Review, 20(3), 203-211. doi: 10.1016/j.hrmr.2009.08.007

Welch, C., \& Wilkinson, I. (2004). The political embeddedness of international business networks. International Marketing Review, 21(2), 216-231. doi: 10.1108/02651330410531411

Woodside, A. G. (2010). Bridging the chasm between survey and case study research: research methods for achieving generalization, accuracy and complexity. Industrial Marketing Management, 39(1), 64-75. doi: 10.1016/j.indmarman.2009.03.017

Yin, R. (2005). Estudo de caso: planejamento e métodos. Porto Alegre: Bookman. 